\title{
Upaya Guru BK untuk Mengentaskan Masalah-Masalah Perkembangan Remaja dengan Pendekatan Konseling Analisis Transaksional
}

\author{
Netrawati, \\ Khairani, \\ Yeni Karneli \\ Universitas Negeri Padang \\ netrawatiunp07@gmail.com
}

\begin{abstract}
Adolesent faces complicated phase because the condition of unstable emotion. In beginning of adolesecence, the development shows strong sensitive and reactive characterisic to an event or social situation. The emotion is negative and temperamental. This research has purpose to: 1) helping student to solve development's problems by using approach of transactional analysis counseling, 2) giving skill for counseling guidance teacher to be able to use approach on transactional analysis counseling by using life position technique, 3) helping adolecent to reach life position in gaining optimal development. This research uses descriptive method through the study of action research which consist of two cycles. The first cycle with counseling plan by using approach of transactional analysis counseling, and second cycle by giving perception and action whith approach of transactional analysis counseling. The subject of this research is student of junior high school as well as counseling guidance teacher. Instrument and technic of data accumulation is interview and observation. The result of it will increase the skill of counseling guidance teacher in doing conseling intervention and group of transactional analysis focuses in solving adolescent's problem. Overall of those two cycles have the change of skill that counseling guidance teacher has to help solving adolescent's development especially showing correct ego state and life script is I am ok you are ok.
\end{abstract}

Keywords: adolescent, transactional counseling analysis, ego state

Abstrak. Remaja berhadapan dengan masa-masa yang menyulitkan karena keadaan emosi yang masih labil. Pada masa remaja awal, perkembangan emosinya menunjukkan sifat sensitif dan reaktif yang sangat kuat terhadap berbagai peristiwa atau situasi sosial, emosinya bersifat negatif dan temperamental. Penelitian ini bertujuan untuk: 1) membantu siswa mengatasi masalah-masalah perkembangan dengan menggunakan pendekatan konseling analisis transaksional, 2) memberikan keterampilan pada guru BK untuk terampil menggunakan pendekatan analisis transaksional dengan mengunakan teknik life position, 3) membantu remaja mencapai life position untuk mencapai

ISLAMIC COUNSELING : Jurnal Bimbingan dan Konseling Islam vol. 2, no. 1, 2018 | p ISSN 2580-3638; e ISSN 2580-3646

http://journal.staincurup.ac.id/index.php/JBK 
perkembangan yang optimal. Penelitian ini menggunakan metode deskriptif melalui penelitian action reseach yang terdiri dari dua siklus. Siklus pertama dengan perencanaan konseling dengan pendekatan analisis transaksional dan siklus kedua dengan memberikan apersepsi dan tindakan dengan pendekatan analisis transaksional. Subjek penelitian adalah siswa SLTP dan guru BK SLTP. Instrumen dan teknik pengumpulan data adalah interview dan observasi. Hasil yang diperoleh berupa dampak bertambahnya keterampilan guru BK dalam melaksanakan intervensi konseling analisis transaksional yang fokus pada pembahasan masalah-maslah remaja. Secara keseluruhan dari kedua siklus tersebut terdapat perubahan keterampilan yang dimiliki guru BK untuk membantu mengatasi masalah-masalah perkembangan remaja khususnya menampilkan ego state yang tepat dan life script saya OK kamu OK.

Kata kunci: remaja, konseling analisis transaksional, ego state

\section{Pendahuluan}

Masa remaja seringkali dihubungkan dengan mitos dan streotip mengenai penyimpangan dan ketidakwajaran. Hal tersebut dapat dilihat dari banyaknya teori-teori perkembangan yang membahas ketidakselarasan, gangguan emosi dan gangguan perilaku sebagai akibat dari tekanan-tekanan yang dialami remaja karena perubahan-perubahan yang terjadi pada dirinya maupun akibat perubahan lingkungan. Sejalan dengan perubahan-perubahan yang terjadi dalam diri remaja, mereka juga dihadapkan pada tugas-tugas yang berbeda dari tugas pada masa kanak-kanak.

Sebagaimana setiap individu dapat mengetahui, dalam setiap fase perkembangan, termasuk pada masa remaja, individu memiliki tugas-tugas perkembangan yang harus dipenuhi. Apabila tugas-tugas tersebut berhasil diselesaikan dengan baik, maka akan tercapai kepuasan, kebahagian dan penerimaan dari lingkungan. Keberhasilan individu memenuhi tugas-tugas itu juga akan menentukan keberhasilan individu memenuhi tugas-tugas perkembangan pada fase berikutnya. Tugas-tugas perkembangan pada masa remaja yang disertai oleh berkembangnya kapasitas intelektual, stres dan harapan-harapan baru yang dialami remaja membuat mereka mudah mengalami gangguan baik berupa gangguan pikiran, perasaan maupun gangguan perilaku. Stres, kesedihan, kecemasan, kesepian, keraguan pada diri remaja membuat mereka mengambil resiko dengan melakukan kenakalan. ${ }^{1}$

Tekanan-tekanan sebagai akibat perkembangan fisiologis pada masa remaja, ditambah dengan tekanan akibat perubahan kondisi sosial budaya, serta perkembangan ilmu pengetahuan dan teknologi yang demikian pesat, seringkali mengakibatkan timbulnya masalah-masalah psikologis berupa gangguan

\footnotetext{
${ }^{1}$ Sanktrock, J.W, Perkembangan Anak. Jilid 1 Edisi Kesebelas. (Jakarta: Erlangga, 2007)
} 
penyesuaian diri atau gangguan perilaku. Beberapa bentuk gangguan perilaku ini dapat digolongkan dalam delinkuensi. Perilaku delinkuensi yang dialami remaja merupakan salah satu masalah remaja yang seyogyanya mendapatkan perhatian khusus.

Remaja di sekolah terkadang memperlihatkan masalah- masalah yang bersumber dari lingkungan dan tidak terpenuhinya tugas perkembangan dengan baik. Masalah perilaku yang dialami remaja di sekolah dapat dikatakan masih dalam kategori yang bisa dianggap wajar, tapi perlu mendapatkan perhatian dari guru khususnya guru BK. Masalah-masalah remaja tentunya tidak dapat dibiarkan begitu saja karena akan mempengaruhi perkembangan remaja. ${ }^{2}$ Oleh karena itu perlu peran guru BK atau konselor untuk mengarahkan, membimbing dan mendampingi siswa dalam menghadapi masalah-masalah di sekolah. Permasalahan remaja khususnya yang terkait dengan tugas perkembangan perlu mendapatkan penanganan yang profesional.

Profesionalitas seorang guru dalam melaksanakan tugas sebagai pendidik sangatlah penting. Semakin guru itu bisa menunjukkan kinerja yang baik, maka siswa akan dapat merasakan manfaat dari pelayanan guru tersebut. Guru Bimbingan dan Konseling (BK) merupakan salah satu tenaga pendidik yang dapat membantu masalah-masalah remaja di sekolah. Keberadaan bimbingan dan konseling di sekolah dijadikan tempat untuk membantu memandirikan siwsa agar mereka mampu berkembang sesuai dengan tugas-tugas perkembangannya.

Dalam membantu permasalahan siswa terkait dengan tugas-tugas perkembangannya dapat dibantu dengan pendekatan konseling analisis transaksional. Pada pendekatan ini guru BK akan membantu siswa untuk menampilkan ego state yang tepat sehingga dapat memenuhi tugas-tugas perkembangannya. Permasalahan-permasalahan yang dialami siswa akan dianalisis dengan strategi life position supaya siswa dapat menampilkan perilaku yang seharusnya.

Untuk membantu permasalahan remaja yang terkait dengan perkembangannya perlu pelayanan yang khusus sehingga dapat dibantu dengan optimal. Permasalahan remaja ini harus dicarikan solusinya. Salah satu solusinya adalah dengan program konseling analisis transaksional. Konseling analisis transaksional digunakan untuk menganalisis sampai melakukan prognosis kepada siswa remaja. Pendekatan analisis transaksional merupakan salah satu cara untuk membantu permasalahan-permasalahan remaja dengan tujuan;

1. Membantu siswa mengatasi masalah-masalah perkembangan dengan menggunakan pendekatan konseling analisis transaksional.

2 Netrawati, Furqon, Yusuf, Rusmana, Solving adolescent verbal aggressions through transactional analysis counseling approach. (Journal of education and practice . (2016). Vol.7 No. 18 
2. Menggunakan analisis ego state untuk memfasilitasi perubahan perilaku.

3. Membantu remaja mencapai life position untuk mencapai perkembangan yang optimal

4. Memberikan keterampilan pada guru BK untuk terampil menggunakan pendekatan analisis transaksional dengan mengunakan teknik life position.

5. Dengan pendekatan analisis transaksional guru BK dapat membantu siswa mencapai life position Saya OK, Kamu OK

Pendekatan konseling Analisis transaksional salah satu pendekatan yang menekankan pada hubungan interaksional mencakup aspek-aspek kepribadian dan dinamika sosial yang disusun berdasarkan pengalaman. Pendekatan AT dalam mencapai tujuan mengarahkan siswa fokus pada situasi "di sini dan sekarang", dengan mengajarkan pemodelan perilaku yang tepat, dan membantu siswa menetapkan tujuan pribadi yang akan memberikan bantuan pada pencapaian perkembangan yang optimal.

\section{Landasan Teori}

\section{Remaja dan Permasalahannya}

Remaja merupakan individu yang sedang mengalami masa pubertas dimana perkembangan fisik dan mental berkembang secara pesat. Masa remaja merupakan masa awal untuk menuju proses mencapai dewasa. Pada masa remaja banyak mengalamai perubahan fisik maupun psikis. Masa remaja adalah masa transisi dimana terjadi gejolak dalam dirinya untuk menunjukkan eksistensi diri. Fase remaja merupakan masa perkembangan individu yang sangat penting. Harold Alberty mengemukakan bahwa masa remaja merupakan suatu periode dalam perkembangan yang dijalani seseorang yang terbentang sejak berakhirnya masa kanak-kanak sampai dengan awal masa dewasa. Masa remaja merupakan masa yang amat kritis yang mungkin dapat merupakan the best of time and the worst of time. ${ }^{3}$ Selanjutnya Havighurst menjelaskan tugas perkembangan yang seharusnya dicapai remaja adalah: (1) menguasai kemampuan membina hubungan baru yang lebih matang dengan teman sebaya atau berbeda jenis kelamin, (2) menguasai kemampuan melaksanakan peran sosial sesuai dengan jenis kelamin, (3) menerima keadaan fisik dan mengaktualisasikan secara efektif, (4) mencapai kemerdekaan emosional dari orangtua dan orang dewasa lainnya, sehingga remaja mengembangkan kasih sayang pada orangtua, perasaan hormat terhadap orang dewasa dan ikatan emosional dengan lawan jenis, (5) memiliki kemampuan untuk mandiri secara ekonomi, sehingga muncul dorongan untuk mencari biaya hidup sendiri, (6) memiliki kemampuan untuk memilih dan mempersiapkan diri untuk karir (7), berkembangnya keterampilan intelektual, dan konsep-konsep yang perlu untuk menjadi warga negara yang baik, dan (8) memiliki keinginan untuk bertanggung jawab terhadap tingkah laku sosial.

\footnotetext{
${ }^{3}$ Sanktrock, J.W, Perkembangan Anak. Jilid 1 Edisi Kesebelas. (Jakarta: Erlangga, 2007)
} 
Masa remaja disebut juga masa untuk menemukan identitas diri (self identity). Usaha pencarian identitas pun, banyak dilakukan dengan menunjukkan perilaku coba-coba, perilaku imitasi atau identifikasi. Ketika remaja gagal menemukan identitas dirinya, dia akan mengalami krisis identitas atau identity confusion, sehingga mungkin saja akan terbentuk sistem kepribadian yang bukan menggambarkan keadaan diri yang sebenarnya.Reaksireaksi dan ekspresi emosional yang masih labil dan belum terkendali pada masa remaja dapat berdampak pada kehidupan pribadi maupun sosialnya. Pertengkaran dan perkelahian seringkali terjadi akibat dari ketidakstabilan emosi remja. ${ }^{4}$

Masa remaja ditandai dengan adanya berbagai perubahan, baik secara fisik maupun psikis. Adanya perubahan yang terjadi pada remaja dapat menimbulkan problema atau masalah tertentu pada dirinya. Apabila masalah remaja tidak disertai dengan upaya pemahaman diri dan pengarahan diri secara tepat, dapat menjurus pada berbagai tindakan kenakalan remaja dan kriminal. Permasalahan yang terjadi pada remaja sangat bervariasi mulai dari masalah sosial, pribadi, belajar dan individu. Permasalahan remaja dapat diklasifikasikan sebagai berikut: ${ }^{5}$

a. Permasalahan berkaitan dengan perkembangan kognitif dan bahasa

Pada masa remaja awal ditandai dengan perkembangan kemampuan intelektual yang pesat. Namun ketika, si remaja tidak mendapatkan kesempatan pengembangan kemampuan intelektual, terutama melalui pendidikan di sekolah, maka boleh jadi potensi intelektualnya tidak akan berkembang optimal. Begitu juga masa remaja, terutama remaja awal merupakan masa terbaik untuk mengenal dan mendalami bahasa asing. Namun dikarenakan keterbatasan kesempatan dan sarana dan prasarana, menyebabkan si remaja kesulitan untuk menguasai bahasa asing. Tidak bisa dipungkiri, dalam era globalisasi sekarang ini, penguasaan bahasa asing merupakan hal yang penting untuk menunjang kesuksesan hidup dan karier seseorang. Namun dengan adanya hambatan dalam pengembangan ketidakmampuan berbahasa asing tentunya akan sedikit-banyak berpengaruh terhadap kesuksesan hidup dan kariernya. Terhambatnya perkembangan kognitif dan bahasa dapat berakibat pula pada aspek emosional, sosial, dan aspek-aspek perilaku dan kepribadian lainnya.

\footnotetext{
${ }^{4}$ Mudjiran, dkk, Perkembangan Peserta Didik. (Padang: UNP Press, 2007)

${ }^{5}$ Sarwono, S. W, Psikologi Remaja (Jakarta: Grasindo Persada 2010)
} 
b. Permasalahan berkaitan dengan perkembangan perilaku sosial, moralitas dan keagamaan.

Masa remaja disebut pula sebagai masa social hunger (kehausan sosial), yang ditandai dengan adanya keinginan untuk bergaul dan diterima di lingkungan kelompok sebayanya (peergroup). Penolakan dari peer group dapat menimbulkan frustrasi dan menjadikan dia sebagai isolated dan merasa rendah diri. Namun sebaliknya apabila remaja dapat diterima oleh rekan sebayanya dan bahkan menjadi idola tentunya ia akan merasa bangga dan memiliki kehormatan dalam dirinya. Problema perilaku sosial remaja tidak hanya terjadi dengan kelompok sebayanya, namun juga dapat terjadi dengan orang tua dan dewasa lainnya, termasuk dengan guru di sekolah. Hal ini disebabkan pada masa remaja, khususnya remaja awal akan ditandai adanya keinginan yang ambivalen, di satu sisi adanya keinginan untuk melepaskan ketergantungan dan dapat menentukan pilihannya sendiri, namun di sisi lain dia masih membutuhkan orang tua, terutama secara ekonomis. Sejalan dengan pertumbuhan organ reproduksi, hubungan sosial yang dikembangkan pada masa remaja ditandai pula dengan adanya keinginan untuk menjalin hubungan khususdengan lain jenis dan jika tidak terbimbing dapat menjurus tindakan penyimpangan perilaku sosial dan perilaku seksual. Pada masa remaja juga ditandai dengan adanya keinginan untuk mencoba-coba dan menguji kemapanan norma yang ada, jika tidak terbimbing, mungkin saja akan berkembang menjadi konflik nilai dalam dirinya maupun dengan lingkungannya.

c. Permasalahan berkaitan dengan perkembangan kepribadian, dan emosional.

Masa remaja disebut juga masa untuk menemukan identitas diri (self identity). Usaha pencarian identitas pun, banyak dilakukan dengan menunjukkan perilaku coba-coba, perilaku imitasi atau identifikasi. Ketika remaja gagal menemukan identitas dirinya, dia akan mengalami krisis identitas atau identity confusion, sehingga mungkin saja akan terbentuk sistem kepribadian yang bukan menggambarkan keadaan diri yang sebenarnya. Reaksi-reaksi dan ekspresi emosional yang masih labil dan belum terkendali pada masa remaja dapat berdampak pada kehidupan pribadi maupun sosialnya. Dia menjadi sering merasa tertekan dan bermuram durja atau justru dia menjadi orang yang berperilaku agresif. Pertengkaran dan perkelahian seringkali terjadi akibat dari ketidakstabilan emosinya.

\section{Konsep Konseling Analisis Transaksional (AT)}

Analisis transaksional (AT) dimulai oleh Erick Berne, ide analisis transaksional terutama berguna untuk membantu remaja memperbaiki hubungan mereka untuk memahami prinsip-prinsip komunikasi yang efektif dan menghargai orang lain dalam kehidupan. Konsep analisis transaksional 
menarik bagi banyak terapis karena memberikan penjelasan-penjelasan mengenai perilaku-perilaku komunikasi yang mudah diikuti. ${ }^{6}$

Transaksional adalah hubungan komunikasi antara seseorang dengan orang lain. Dengan demikian analisis transaksional lebih banyak digunakan dalam suasana kelompok. Dalam pendekatan ini yang perlu dianalisis menyangkut komunikasi antara dua orang atau lebih yang meliputi bagaimana bentuk, cara dan isi komunikasi siswa. ${ }^{7}$ Dari hasil analisis dapat ditarik kesimpulan apakah transaksi yang berjalan tersebut dapat berlangsung secara benar dan tepat atau dalam keadaan tidak benar dan tidak tepat. Kata transaksi selalu mengacu pada proses pertukaran dalam suatu hubungan. Analisis transaksional sebenarnya bertujuan untuk mengkaji secara mendalam proses transaksi (siapa-siapa yang terlibat di dalamnya dan pesan apa yang dipertukarkan).

\section{Ego state}

Transaksional analisis meyakini bahwa pada diri setiap manusia itu terdapat unsur-unsur kepribadian yang terstruktur dan itu merupakan suatu kesatuan yang disebut dengan "ego state" atau pernyataan ego. ${ }^{8}$ Setiap manusia memperlihatkan tiga macam ego sate: Parent, Adult, dan Child. Setiap individu dalam sebuah kelompok sosial secara dominan memperlihatkan salah satu keadaan ego. ${ }^{9}$ berikut:

Ego state yang terjadi pada individu dapat diklasifikasikan sebagai

a. Ego state child, yaitu pernyataan ego dengan ciri- ciri pribadi anak seperti manja, riang, lincah, cengeng, rewel, tingkah laku lucu dan sebagainya. Ego state child ini juga terdiri dari tiga bagian yaitu, (1) adapted child atau kekanakkanakan, unsur ini kurang baik apabila ditampilkan oleh seseorang dalam berkomunikasi, karena sering tidak disukai oleh orang lain dan tidak menunjukkan adanya kematangan dalam memperoleh sentuhan; (2) natural child ego state anak yang alamiah yaitu bebas dan senang, ini dianggap baik, natural child ini menunjukkan kealamiahan dan tidak dibuat-buat serta bersifat spontan; (3) little professor sering digunakan seseorang untuk menciptakan suasana yang lucu dan menyenangkan.

${ }^{6}$ Geldard Kathryn \& G. David, Practical Counselling Skill: an Integrative approach, ( London Sage Publicatin, 2005)

${ }^{7}$ Corey, M. S., Corey, G., \& Corey, C, Groups: Process and practice (8th ed., (PacificGrove, CA: Brooks/Cole, 2009)

${ }^{8}$ Stewart, I \& Joines, V, TA today anew introduction to transactional analysis, (Lifespace Publishing, Nottingham: Russel Press Ltd, 2008)

${ }_{9}$ Nelson Richard, J, Introduction to counseling skills: text and activities, ( London: Sage Publication, 2006) 
b. Ego state parent yaitu pernyataan ego orang tua. Ego state ini diwarnai oleh moral dan nilai-nilai. Ego state ini terbagi dua yaitu, (1) critical parent yaitu orang tua yang selalu mengkritik, bagian ini dinilai sebagai penampilan ego state yang kurang baik. Unsur ego state ini apabila muncul dalam tingkah laku sering berbentuk omelan, judes, mengkritik dan sebagainya; (2) nurturing parent, orang tua yang merawat wujud tingkah lakunya seperti merawat, dan membimbing.

Sikap orangtua yang diwakili dalam perilaku dapat terlihat dan terdengar dari tindakan maupun tutur kata atau ucapan-ucapannya. Seperti tindakan menasihati orang lain, memberikan hiburan, menguatkan perasaan, memberikan pertimbangan, membantu, melindungi, mendorong untuk berbuat baik adalah sikap yang nurturing parent (NP). Sebaliknya ada pula sikap orang tua yang suka menghardik, membentak, menghukum, berprasangka, melarang, semuanya disebut dengan sikap yang critical parent (CP)

c. Ego state adult yaitu pernyataan ego orang dewasa, dengan ciri-ciri realistis, berdasarkan pemikiran apa adanya, memaparkan fakta, dengan melalui proses menimbang mengingat dan memutuskan. Ego state ini diwarnai oleh penekanaan pada rasio dan kenyataan.

d. Setiap individu menurut Berne memiliki sikap orang dewasa. Sikap orang dewasa umumnya pragmatis dan realistis, mengambil kesimpulan atau keputusan berdasarkan fakta-fakta yang ada, suka bertanya, mencari informasi, menunjukkan fakta-fakta, bersifat rasional, tidak emosional, bersifat objektif dan sebagainya.

Sikap lain yang dimiliki setiap individu adalah egostate anak-anak. Dibedakan antara natural child (NC) yang ditunjukkan dalam sikap ingin tahu, berkhayal, kreatif, memberontak. Sebaliknya yang bersifat adapted child (AC) adalah mengeluh, ngambek, suka pamer, dan bermanja diri.

\section{Posisi Hidup (Life Positions)}

Pendekatan analisis transaksional melihat kebutuhan untuk memperoleh posisi hidup, ialah hubungan yang dirasakan oleh seseorang antara diri sendiri dengan orang lain. Misalnya orang berkata pada diri sendiri bagaimana keadaan (posisi) hidup saya ketika berhubungan dengan orang lain. Analisis transaksional menurut Stewart I \& Joines Vann membagi empat posisi hidup yang sering dipilih oleh seseorang; ${ }^{10}$

a. Saya OK, kamu OK. Posisi ini adalah posisi yang dipilih seseorang apabila dia merasa dirinya baik $(\mathrm{OK})$ dan orang lain dirasakan juga baik $(\mathrm{OK})$. Orang

${ }^{10}$ Stewart, I \& Joines, V, TA today anew introduction to transactional analysis, (Lifespace Publishing: Nottingham: Russel Press Ltd, 2008) 
yang berada pada posisi ini, hubungan yang dilakukannya sedang berjalan dan meningkat kearah yang lebih baik dan berjalan secara evolusioner (berubah secara lambat). Remaja yang termasuk pada perilaku agresif dapat dibangun posisi hidupnya saya OK kamu OK. Perilaku agresif dan kenakalan yang terjadi pada remaja disebabkan karena posisi hidupnya tidak bisa seperti ini.

b. Saya OK kamu tidak OK. Posisi hidup yang dipilih seseorang apabila dia merasa dirinya baik $(\mathrm{OK})$ dan orang lain tidak OK. Hubungan ini sifatnya cenderung merubah pihak kedua, biasanya bersifat revolusioner (berubah cepat). Orang yang memilih posisi ini misalnya seperti orang yang bersiteru dengan orang lain, seperti terjadinya pertentangan, perkelahian atau selisih paham.

c. Saya tidak OK kamu OK. Orang yang berada pada posisi ini merasa dirinya tidak baik dan hanya orang lain yang baik (OK). Hubungan yang dirasakannya adalah hubungan yang mengubah "saya oleh kamu" dan sifat hubungannya adalah devolusioner (mundur secara lambat). Orang yang berada pada posisi ini pada dirinya ada perasaan takut, terancam, terhina, rendah diri dan sebagainya.

d. Saya tidak OK kamu tidak OK. Orang yang berada pada posisi ini merasa bahwa dirinya sendiri tidak berdaya dan orang lain dirasakannya juga tidak berdaya. Contohnya adalah orang putus asa, frustasi dan sebagainya.

Dalam memenuhi kebutuhan hidup untuk memperoleh sentuhan, individu selalu menempati tipe-tipe transaksi tertentu. Corey \& Corey membagi jenis transaksi menjadi tiga: ${ }^{11}$

a. Transaksi sejajar, adalah individu yang berkomunikasi dengan penampilan ego state tertentu dan ditujukan pada penampilan ego state tertentu pula, maka respon orang yang menjadi lawan komunikasinya, ditampilkan juga seperti apa yang diharapkan. Transaksi komplementer adalah jenis transaksi yang terbaik dalam komunikasi antar pribadi karena terjadi kesamaan makna terhadap pesan yang mereka pertukarkan, pesan yang satu dilengkapi oleh pesan yang lain meskipun dalam jenis sikap ego yang berbeda.

b. Transaksi silang, adalah penampilan ego state seseorang dan respon yang diharapkan tidak sejajar atau silang yaitu tidak sebagaimana yang diharapkan. Transaksi silang terjadi manakala pesan yang dikirimkan komunikator tidak mendapat respon sewajarnya dari komunikan. Akibat dari transaksi silang adalah terputusnya komunikasi antar pribadi karena kesalahan dalam memberikan makna pesan.

${ }^{11}$ Corey, M. S., Corey, G., \& Corey, C, Groups: Process and practice (8th ed., (PacificGrove, CA: Brooks/Cole, 2009) 
c. Transaksi terselubung, adalah penampilan ego state oleh orang yang berkomunikasi tersebut memiliki maksud yang terselubung seperti kiasan atau sindiran dan sejenisnya.

\section{Metode Penelitian}

Metode yang digunakan dalam penelitian ini adalah penelitian action research dalam seting pelayanan bimbingan dan konseling dengan mengunakan pendekatan anaisis transaksional. Penelitian ini dilakukan dengan tujuan untuk membantu memecahkan masalah guru BK SLTP yang ada di sekolah. Dengan metode penelitian action research dapat menguji ketepatan guru BK dalam memberikan treatment kepada siswa remaja yang mengalami masalah dengan perkembangannya. Model yang digunakan dalak penelitian ini dibagi empat komponen; 1) planing, 2) acting, 3) observing, 4) reflecting. Subjek penelitian adalah 100 orang siswa SLTP dan 25 orang guru BK. Penelitian dilakukan di Kabupaten Padang Pariaman.

\section{Temuan Penelitian dan Pembahasan}

Pada setiap perkembangan kehidupan manusi, individu dituntut untuk menguasai kemampuan berperilaku yang menjadi ciri bahwa perkembangannya berhasil dan normal. Pada fase tertentu remaja tidak mempunyai kemampuan berperilaku sepatutnya, sesuai dengan tugas-tugas perkembangan maka diannggap individu itu mengalami kelambatan perkembangan, atau penyimpangan perkembangan. Berdasarkan hasil observasi diperoleh temuan permasalahan yang dialami remaja dapat dikelompokkan pada : 1) masalah karakter, 2) masalah pembelajaran, 3) masalah addiction game online, 4) masalah tawuran, 5) masalah perilaku agresif, 6) masalah identitas diri. Pencapaian tugastugas perkembangan pada diri remaja belum optimal, kecenderungan remaja masih memerlukan arahan dan bimbingan dari orangtua dan guru untuk mencapai perkembangan yang optimal. Perhatian yang diperlukan remaja dalam mencapai tugas-tugas perkembangan yaitu mendapatkan tindakan segera dari keluarga dan sekolah. Hasil temuan dari penelitian sebelum memberikan workshop pada guru BK SLTP diperoeh data, bahwa pada umumnya guru BK dalam memberikan bantuan untuk tugas perkembangan remaja belum ada memakai pendekatan konseling analisis transaktional. Selama ini guru BK cenderung menggunakan konseling dengan pendekatan eklektik, dimana dasar teori dan teknik yang digunakan masih perlu ditingkatkan. Pendekaatan analisis transaksional dapat membantu permasalahan remaja yang terkait dengan komunikasi, perkembangan dan perilaku maladaptif. Membantu permasalahan siswa remaja dengan pendekatan analisis transaksional merupakan pembaharuan yang belum pernah dilakukan guru BK SLTP untuk mencapai tugas-tugas 
perkembangan. $^{12}$ Pendekatan sosiodrama dengan pendekatan analisis transaksional dapat membantu mengatasi permasalahan remaja yang terkait dengan tugas perkembangan. Apabila setiap fase perkembangan kehidupan manusia berhasil atau sukses dicapai, maka individu itu akan mengalami perasaan bahagia dan menjalani kehidupan dengan perasaan sukses baik secara emosional, intelektual dan moral. ${ }^{13}$

Siswa remaja untuk mencapai tugas-tugas perkembangannya terkadang menghadapi masalah, untuk itu perlu peran guru BK. Guru BK dapat membantu permasalahan yang dihadapi siswa remaja dengan pendekatan konseling analisis transaksional. Setelah guru BK mendapatkan workshop terdapat penambahan pengetahuan dan wawasan dari guru BK dalam membantu permasalahan remaja dengan pendekatan konseling analisis transaksional. Dari hasil refleksi pada umumnya guru BK sudah memiliki pengetahuan dan keterampilan untuk mencoba melaksanakan pendekatan konseling analisis transaksional untuk membantu masalah-masalah perkembangan remaja. Sehingga dapat disimpulkan konseling analisis transaksional tepat digunakan dalam membantu masalah-masalah perkembangan siswa remaja.

\section{Kesimpulan}

Dari hasil penelitian dapat disimpulkan secara umum setelah dilakukan workshop konseling analisis transaksional untuk membantu masalah-masalah perkembangan remaja memberikan dampak positif pada guru BK. Dampak yang diberikan yaitu, sebelumnya guru BK belum pernah menggunakan pendekatan analisis transaksional untuk membantu siswanya, sekarang setelah workshop mereka sudah memiliki keterampilan untuk menggunakan pendekatatan analisis transaktional. Guru sudah memahami analisis dengan menguankan ego state, life position, dan analisis transaksional dalam membantu masalah-masalah perkembangan remaja. hal tersebut dapat dilihat dari perbandingan antara hasil siklus kesatu dengan hasil siklus kedua, yaitu adanya peningkatan pengetahuan dan keterampilan guru BK dalam melaksanakan pendekatan konseling analisis transaksional.

\footnotetext{
${ }^{12}$ Corey, G., Corey, M. S., Callahan, P., \& Russell, J. M, Group techniques (4th ed.), Pacific Grove, CA: Brooks/Cole, (2010)

${ }^{13}$ Ingrid, B., Robert, and Cristina, Efficacy of in intervention reduce the use of violence and aggresion: An experimental evaluation with adolescent in Germany. (Journal of Youth Adolescence. 41:105-120, 2012).
} 
90 | ISLAMIC COUNSELING : Jurnal Bimbingan dan Konseling Islam, vol. 2, no. 1, 2018

\section{Bibliografi}

Berg, R.C, Landrent, G.L \& Kevin A.F. (2006). Group Counseling Concepts and Procedures. New York. Published in Great Britain byRoutledge Taylor \& Francis Group

Clarkson, P. (1992). Transactional analysis psychotherapy an integrated approach. London and New York. Rouleedge.

Corey, G., Corey, M. S., Callahan, P., \& Russell, J. M. (2010). Group techniques (4th ed.).Pacific Grove, CA: Brooks/Cole.

Corey, M. S., Corey, G., \& Corey, C. (2009). Groups: Process and practice (8th ed.). PacificGrove, CA: Brooks/Cole.

Geldard Kathryn \& G. David, (2005). Practical Counselling Skill: an Integrative approach. London Sage Publicatin.

Ingrid, B., Robert, and Cristina. (2012). Efficacy of in intervention reduce the use of violence and aggresion: An experimental evaluation with adolescent in Germany. Journal of Youth Adolescence. 41:105-120.

Jacobs E, Masson Robert L \& Harvill Riley L. \& Schimmel Christine. 2012. Group Counseling Strategies and Skills. West Virginia University. Brooks/Cole, Cengage Learning. Publisher: Linda Schreiber-Ganster.

Mudjiran, dkk (2007) Perkembangan Peserta Didik. Padang. UNP Press

Natawidjaja, Rochman. (2009). Konseling Kelompok Konsep Dasar dan Pendekatan, Bandung. Rizqi Press.

Nelson Richard, J (2006) Introduction to counseling skills: text and activities. London. Sage Publication.

Netrawati, Furqon, Yusuf, Rusmana. (2016). Solving adolescent verbal aggressions through transactional analysis counseling approach. Journal of education and practice. Vol.7 No. 18

Rusmana, Nandang. 2009. Bimbingan dan Konseling Kelompok di Sekolah Metode, Teknik dan Aplikasi). Bandung. Rizqi Press

Sanktrock, J.W. ( 2007). Perkembangan Anak. Jilid 1 Edisi Kesebelas. Jakarta: Erlangga

Sarwono, S. W (2010). Psikologi Remaja. Jakarta. Grasindo Persada

Stewart, I \& Joines, V. (2008). TA today anew introduction to transactional analysis. Lifespace Publishing, Nottingham. Russel Press Ltd. 